\title{
Using operative models (ICF and CBR) within an interprofessional context to address community needs
}

\author{
A Rhoda, ${ }^{1} \mathrm{PhD}$; F Waggie, ${ }^{2} \mathrm{PhD}$; G C Filies, ${ }^{2}$ MPhil; J M Frantz, ${ }^{1} \mathrm{PhD}$ \\ ${ }^{1}$ Department of Physiotherapy, Faculty of Community and Health Sciences, University of the Western Cape, Cape Town, South Africa \\ ${ }^{2}$ Interprofessional Education Unit, Faculty of Community and Health Sciences, University of the Western Cape, Cape Town South Africa
}

Corresponding author: A Rhoda (arhoda@uwc.ac.za)

Background. The use of conceptual frameworks has been advocated when implementing interprofessional initiatives.

Objective. To present the use of the International Classification of Functioning Disability and Health (ICF) and the community-based rehabilitation (CBR) matrix for identifying and addressing the health needs of the community.

Methods. The ICF care plan and the CBR matrix were used to conduct a retrospective document analysis. The documents were completed by interprofessional groups of students who were involved in an interprofessional community-based intervention. Data were captured on a sheet and analysed descriptively using the domains of the ICF and the CBR matrix. Ethical clearance was obtained from the University of the Western Cape, Cape Town, South Africa.

Results. A total of 30 senior nursing, physiotherapy and biokinetics students were divided into groups and interacted with five community-based groups. Each group of students completed one ICF care plan and one CBR matrix. The needs documented in the ICF care plans included impairments, activity limitations, participation restrictions and environmental challenges. Impairments included sensory, motor and psychological impairments, while activity limitations included limitations in activities of daily living and mobility. Limited social interaction and physical environment were identified as experienced environmental challenges. The interventions documented to address these needs included health promotion, prevention, medical care, skills development and facilitation of access to justice.

Conclusion. The ICF and CBR matrix can be used to facilitate students' identification of the needs of communities and the implementation of interventions to address these needs in an interprofessional manner.

Afr J Health Professions Educ 2016;8(2 Suppl 2):214-216. DOI:10.7196/AJHPE.2016.v8i2.850

Identifying educational strategies to assess and address the health needs of communities is a high priority, both nationally and internationally. ${ }^{[1]}$ Clinical training of healthcare professionals occurs in different settings using different learning strategies and activities. One such setting is the community, as community-based education (CBE). According to Villani and Atkins, ${ }^{[2]}$ 'CBE is centred on the student's ability to recognise and support the needs of the surrounding community. In this way, students become accountable for providing values which stem from their freedom to express, develop, and solve the inherent problems or concerns they have for their community.' Community members, lecturers and individuals from different sectors are all involved in this learning process, which is primarily based on the needs of the community. As interprofessional education (IPE) occurs among students from more than one profession, ${ }^{[3]}$ interprofessional CBE could be considered as an educational approach, where learning strongly occurs within communities and with consideration of the needs of communities, with two or more professional groups of students. When implementing community-based IPE initiatives, the use of frameworks has been found beneficial ${ }^{[4,5]}$ and may facilitate the development of IPE competencies such as communication and student learning. ${ }^{[6]}$

In the context of IPE, the International Classification of Functioning, Disability and Health (ICF) may assist students in identifying the needs or challenges experienced by individuals and communities. ${ }^{[7]}$ The $\mathrm{ICF}^{\left[{ }^{[8]}\right.}$ conceptualises functioning in terms of activities and participation, and considers contextual factors, such as environmental and personal factors. The ICF can therefore be used as a tool to assess functioning. ${ }^{[8]}$ Communitybased rehabilitation (CBR), which is encompassed within community development, facilitates the rehabilitation, equalisation of opportunities and social inclusion of persons with disabilities, and can be used to address the needs of communities. The CBR matrix provides a visual illustration of CBR and consists of five components (health, education, livelihood, social and empowerment), each consisting of five elements. The elements of the different components are as follows: health - prevention, promotion, medical care, rehabilitation and assistive devices; education - early childhood, primary, secondary and higher, non-formal and life-long learning; livelihood - skills development, self-employment, financial services, wage employment and social protection; social - relationships, marriage and family, personal assistance, culture and arts, recreation, leisure and sports, and access to justice; and empowerment - communication, social mobilisation, political participation, self-help groups and disabled people's organisations. ${ }^{[5]}$

This short report highlights how a group of interprofessional students can collaboratively identify the needs of individuals and communitybased groups using the ICF, and also highlights possible interventions conceptualised within the CBR matrix.

\section{Methods}

The study sample consisted of a convenient cohort of 30 students from the Departments of Physiotherapy, Nursing and Biokinetics at the University of the Western Cape (UWC), Cape Town, South Africa, who participated in an IPE activity while rotating through a community-based clinical practice placement in 2013. As part of the activity, the students were placed in groups, and engaged with specific community-based organisations (CBOs). The CBOs consisted of a day-care centre for children without disabilities, 


\section{Short Report}

Table 1. ICF domains, CBR domains and CBR elements

\begin{tabular}{|c|c|c|c|}
\hline & & ICF domains & CBR component (CBR elements) \\
\hline $\mathrm{CBO} /$ group & Needs of CBO/group & Assessment & Intervention \\
\hline $\begin{array}{l}\text { Day-care centre for } \\
\text { children without } \\
\text { disabilities }\end{array}$ & $\begin{array}{l}\text { Developmental screening } \\
\text { Stimulation of children }\end{array}$ & $\begin{array}{l}\text { Impairments } \\
\text { None identified } \\
\text { Activity limitations } \\
\text { None identified } \\
\text { Participation restrictions } \\
\text { None identified } \\
\text { Environmental factors } \\
\text { Facilitators } \\
\text { Supportive principal and family } \\
\text { Barriers } \\
\text { Physical environmental - limited space } \\
\text { Attitudinal } \\
\text { Limited space and unfriendly (space and location) }\end{array}$ & $\begin{array}{l}\text { Health } \\
\text { Promotion } \\
\text { Prevention } \\
\text { Medical care } \\
\text { Education } \\
\text { Early childhood } \\
\text { Livelihoods } \\
\text { Skills development }\end{array}$ \\
\hline $\begin{array}{l}\text { Day-care centre for } \\
\text { children with disabilities }\end{array}$ & $\begin{array}{l}\text { Constant care of children } \\
\text { Increased resources } \\
\text { Qualified staff }\end{array}$ & $\begin{array}{l}\text { Impairments } \\
\text { Sensory } \\
\text { Motor } \\
\text { Psychological } \\
\text { Activity limitations } \\
\quad \text { Limitations in activities of daily living and } \\
\text { mobility } \\
\text { Participation restrictions } \\
\text { Limited social interaction } \\
\text { Environmental factors } \\
\text { Barriers } \\
\quad \text { Lack of social support } \\
\text { Limited physical space } \\
\text { Lack of trained healthcare workers }\end{array}$ & $\begin{array}{l}\text { Health } \\
\text { Promotion } \\
\text { Prevention } \\
\text { Rehabilitation } \\
\text { Education } \\
\text { Primary } \\
\text { Life-long learning } \\
\text { Livelihoods } \\
\text { Skills development } \\
\text { Social } \\
\text { Recreation } \\
\text { Leisure } \\
\text { Sport } \\
\text { Personal assistance } \\
\text { Empowerment } \\
\text { Communication }\end{array}$ \\
\hline Frail-care centre (carers) & $\begin{array}{l}\text { Understanding conditions of the } \\
\text { elderly } \\
\text { Training }\end{array}$ & $\begin{array}{l}\text { Impairments } \\
\text { None } \\
\text { Activity limitations } \\
\text { None } \\
\text { Participation restrictions } \\
\text { None } \\
\text { Environmental factors } \\
\text { Barriers } \\
\text { Caregiver knowledge of conditions }\end{array}$ & $\begin{array}{l}\text { Health } \\
\text { Promotion } \\
\text { Prevention } \\
\text { Empowerment } \\
\text { Communication }\end{array}$ \\
\hline Home-based carers & $\begin{array}{l}\text { Access to information } \\
\text { Access to health } \\
\text { professional team }\end{array}$ & $\begin{array}{l}\text { Impairments } \\
\text { None } \\
\text { Activity limitations } \\
\text { None } \\
\text { Participation restrictions } \\
\text { None } \\
\text { Environmental factors } \\
\text { Facilitators } \\
\text { Building } \\
\text { Barriers } \\
\text { Language }\end{array}$ & $\begin{array}{l}\text { Health } \\
\text { Promotion } \\
\text { Prevention } \\
\text { Education } \\
\text { Life-long learning } \\
\text { Skills development } \\
\text { Livelihoods } \\
\text { Self-employment } \\
\text { Social } \\
\text { Culture and arts } \\
\text { Empowerment } \\
\text { Access to justice }\end{array}$ \\
\hline
\end{tabular}

a day-care centre for children with disabilities, a frail-care centre, a homebased care organisation, and a community-based skills development group. The students used the ICF care plan ${ }^{[9]}$ to document the needs of individuals who were part of these organisations. Additionally, the students indicated on the CBR matrix which components and elements were relevant when addressing the identified needs. A document analysis was, therefore, used 


\section{Short Report}

Table 1. (continued) ICF domains, CBR domains and CBR elements

\begin{tabular}{|c|c|c|c|}
\hline \multirow[b]{2}{*}{$\mathrm{CBO} /$ group } & \multirow[b]{2}{*}{ Needs of $\mathrm{CBO} /$ group } & ICF domains & \multirow{2}{*}{$\frac{\text { CBR component (CBR elements) }}{\text { Intervention }}$} \\
\hline & & Assessment & \\
\hline \multirow[t]{13}{*}{ Skills development group } & Financial support & Impairments & Health \\
\hline & Biokinetics input & Blindness & Promotion \\
\hline & & Muscle pain & Prevention \\
\hline & & Activity limitations & Medical care \\
\hline & & None & Education \\
\hline & & Participation restrictions & Life-long learning \\
\hline & & None & Skills development \\
\hline & & Environmental factors & Livelihoods \\
\hline & & Barriers & Self-employment \\
\hline & & Language & Social \\
\hline & & Financial & Culture and arts \\
\hline & & Transport & Empowerment \\
\hline & & & Access to justice \\
\hline
\end{tabular}

to determine both the identified community needs and the interventions suggested by the students. The documents were reviewed by one of the authors (AR) and peer reviewed by another author (JF). The information collected from the documents was captured on a data sheet. Captured data included the CBO needs of the organisations, the ICF domains, the CBR domains and the CBR elements. Names of students and institutions were not identified during the analysis and presentation of the data. Ethical clearance was obtained from UWC (ethics No. 13/3/9).

\section{Results}

The sample of 30 students consisted of 22 nursing, 4 physiotherapy and 4 biokinetics students who had the opportunity to collectively interact with five different community-based groups. When documenting the needs according to the ICF, the students identified mainly environmental barriers experienced by the organisations or groups. Within the context of the CBR matrix, the students highlighted a need for access to justice for the homebased care group that was not documented for the other community-based groups. The ICF domains, CBR domains and CBR elements, as documented by the students, are presented in Table 1 .

\section{Discussion}

The use of frameworks and models is recommended to facilitate student interaction regarding management during IPE initiatives. ${ }^{[6]}$ The ICF and CBR matrix, both developed by the World Health Organization, are two such models. These frameworks were used to facilitate the students' identification of community needs and the suggested interventions to address these needs.
When contextualised within the ICF, the students identified limitations that went beyond identification of impairments. Environmental barriers, which included a lack of physical space and finances, were identified. Lack of skills and social interaction was also highlighted a limitation. ${ }^{[8]}$ To address these challenges, the students highlighted the need for life-long learning, skills development and the facilitation of access to justice. ${ }^{[4]}$

\section{Conclusion}

The ICF and CBR matrix can be used to facilitate students' identification of the needs of communities and the implementation of interventions that are appropriately based on these needs, in an interprofessional manner.

\section{References}

1. Salvatori PS, Berry SC, Eva KW. Implementation and evaluation of an interprofessional education initiative for students in the health professions. Learn Health Soc Care 2007;6(2):72-82. DOI:10.1111/j.1473-6861.2007.00152.x 2. Villani CJ, Atkins D. Community-based education. School Comm J 2000;10(1):39-44.

3. World Health Organization. Transforming and Scaling Up Health Professionals

4. Education and Training: World Health Organization Guidelines, 2013. Geneva: WHO, 2013. http://apps.who.int iris/handle/10665/93635 (accessed 25 July 2016).

5. Tartavoulle TM, English R, Gunaldo T, et al. Using the IDEA framework in an interprofessional didactic elective course to facilitate positive changes in the roles and responsibility competency. J Interprof Educ Prac 2016;2:21e-24e. http://www.jieponline.com (accessed June 2016)

6. World Health Organization. Community-based rehabilitation. http://www.who.int/disabilities/cbr/en/ (accessed 17 August 2016).

7. Allan CA, Campbell WN, Guptill CA, Stephenson FF, Campbell KE. A conceptual model for interprofessiona education: The International Classification of Functioning, Disability and Health (ICF). J Interprof Care 2006;20(3):235-245. DOI:10.1080/13561820600718139

8. Schneider M, Hartley S. International Classification of Functioning, Disability and Health (ICF) and CBR. In: Hartley S, ed. CBR as a Part of Community Development: A Poverty Reduction Strategy. London: University College, London Centre for International Child Health, 2006.

9. World Health Organization. International Classification of Functioning, Disability and Health. Geneva: WHO, 2001. www.who.int/classifications/icf/en/ (accessed July 2016)

10. Snyman S, von Pressentin KB, Clarke M. International Classification of Functioning, Disability and Health: Catalyst for interprofessional education and collaborative practice. J Interprof Care 2015;29(4):313-319. DOI $10.3109 / 13561820.2015 .1004041$ 